\title{
ЭКОЛОГИЯ РАСТЕНИИ
}

УДК 635.928

\section{ЭКОЛОГИЧЕСКАЯ СИТУАЦИЯ И ОСОБЕННОСТИ ВЫРАЩИВАНИЯ ГАЗОНОВ В СТЕПНОЙ 3ОНЕ РОССИИ}

\author{
$\odot_{2010}$ Гречушкина-Сухорукова Л.А. \\ Ставропольский ботанический сад им В.В, Скрипчинского \\ СНИИСХ Россельхозакадемии
}

Представлена оценка результатов воздействия засушливых периодов, приводящих к выгоранию различной интенсивности неорошаемых газонов различных типов, на период от 20 до 90 дней. Выгоревшие газоны теряют декоративность и средообразующую способность: температура на их поверхности на $6-9^{\circ} \mathrm{C}$ выше, чем на орошаемом газоне, а влажность ниже на 20-29\%.

The article is devoted to the results assessment of the influence of droughty periods which lead to parching of different intensity of nonirrigated lawns of different types for the period from 20 to 90 days. Parched lawns lose their decorative power and ability to form the environment: temperature on their surface is $6-9^{\circ} \mathrm{C}$ higher then on the irrigated lawns and wetness is $20-29 \%$ lower.

Ключевые слова: газоны, засушливый период, выгорание, водный десицит, средообразующая способность.

Keywords: lawns, droughty period, parched lawns, water deficit, the ability of lawns to form the environment.

Экологический каркас городских территорий, под которым понимается пространственное сочетание природных и культурных ландшафтов, призван обеспечивать стабильность и оптимизацию среды в урбоэкосистемах. Наиболее эффективным и универсальным средством ее улучшения являются зеленые насаждения. В системе городского озеленения газоны выступают как основа пространственной архитектурно-планировочной организации всех видов городских ландшафтов - от промышленных, транспортных, гидротехнических до садово-парковых и селитебных. Велика экологическая роль газонов. Они принимают участие в воспроизводстве и оптимизации основных компонентов городской среды, способствуют увеличению ее санитарногигиенической комфортности. Газоны улучшают микроклимат, повышают влажность воздуха и стабилизируют температуру в приземном слое; увеличивают выработку кислорода и фитонцидов; поглощают и нейтрализуют техногенные загрязнения; предотвращают водную и ветровую эрозию $[2,9,15]$.

В ряду исследований по прогнозированию успешности выращивания, оценке перспективности и оптимизации ассортимента газонных трав, особую актуальность приобретает изучение влияния на их рост и развитие экологических условий конкретных мест их выращивания. В целом, число всевозможных экологических факторов урбосреды, воздействующих на газоны, потенциально неограниченно. Нередко, в городских условиях газонные покрытия испытывают различные негативные воздействия из-за прямых механических повреждений автотранспортом, во время строительных работ и при систематическом вытаптывании, а также в результате токсического воздействия повышенных концентраций тяжелых металлов, выделяемых промышленностью и транспортом и использования противогололедных смесей и солей. В степной зоне дополнительные стрессовые условия создаются за счет специфических климатических условий. В засушливых агроклиматических районах Ставропольского края вегетация газонных и дернообразующих трав зачастую проходит в условиях жесткого гидротермического стресса, связанного с бездождевыми периодами разной продолжительности. При недостаточном поливе или при его полном отсутствии нарушается водный режим газонных растений, происхоит их перегрев, угнетение роста, потеря декоративности и средообразующей роли. В периоды длительных засух газо- 
ны могут полностью выгорать. Если декоративные и спортивные газоны городов с разной степенью периодичности поливаются, то дерновые покрытия специального назначения (задерненные разделительные полосы шоссе, откосы транспортных магистралей и гидротехнических сооружений, отвалы тепловых электростанций и перерабатывающих предприятий и др.), которые занимают большие площади, как правило, культивируются на фоне естественного влагообеспечения.

В задачу настоящего исследования входила оценка воздействия засушливых периодов различной продолжительности и интенсивности на особенности вегетации городских газонных покрытий разного типа и культивируемые в экспериментальных условиях газонные травы различных экологических групп в условиях орошения и без него, изучение средообразующей способности газонных трав вегетирующих и выгоревших газонов.

Материал и методика. Объектом исследования были газонные травостои г. Ставрополя и Ставропольского края, а также коллекция, насчитывающая 230 образцов интродуцированных сортовых, инорайонных и местных дикорастущих газонных и дернообразующих злаков, культивируемых на экспериментальном участке Ставропольского ботанического сада (630-640 м над уровнем моря; V умеренно влажный агроклиматический район, ГТК $1,1-1,3, \sum t^{\circ}>10^{\circ} \mathrm{C}-2600$ 3200 ; почва - выщелоченные деградированные черноземы; среднегодовое количество осадков 633 мм, из них в холодный период (IX-III) выпадает - 192 мм, в теплый период (IV-X) - 471 мм; среднегодовая температура $+7,5^{\circ} \mathrm{C}$; самый холодный месяц - январь $\left(-4,9^{\circ} \mathrm{C}\right)$; самый теплый июль $\left(19,6^{\circ} \mathrm{C}\right)$; абсолютный температурный минимум $--31^{\circ} \mathrm{C}$, абсолютный максимум $-+37^{\circ} \mathrm{C}$, продолжительность безморозного периода - 142-213 дней).

При микроклиматическом исследовании выгоревших и вегетирующих газонов нами учитывались следующие метеорологические элементы: температура и влажность воздуха на высоте 1,5 м, на поверхности обнаженной почвы, выгоревшего и вегетирующего, периодически орошаемого газона, а также на глубине 5-10-15 см. Измерения температуры проводились ртутными термометрами. Относительная влажность воздуха определялась с помощью аспирационного психрометра и вычислялась по психрометрическим таблицам $[12,14,16]$. Кроме того, были использованы данные агрометеопоста Ставропольского ботанического сада. Влажность почв определялась в соответствии стандартной методикой [10].

Полученные данные обработаны общепринятыми статистическими методами[13].

Результаты и их обсуждение. В ходе эволюции наземных растений в качестве механизмов, обеспечивающих их выживание в аридных условиях, выработались сезонные ритмы, дающие им возможность использовать для вегетации наиболее благоприятные периоды и резко сокращать жизнедеятельность, вплоть до впадения в состояние покоя или анабиоза, во время засухи. Многолетние растения степей в аридных условиях с резко выраженным летним сухим периодом имеют «двухтактный» ритм сезонного развития. Весенняя вегетация сменяется засушливым периодом середины и конца лета, приостановкой развития из-за сильного обезвоживания и снижения интенсивности физиологических процессов, потерей части листовой поверхности (выгорание и высыхание) Такое состояние получило название «периода полупокоя». Он длится вплоть до осенних дождей, после которых, степные растения возобновляют вегетацию. Летний полупокой у травянистых растений в аридных условиях обычно связывают с дефицитом почвенной влаги и атмосферной засухой при высоких температурах воздуха [5].

Ставропольский край практически на всей территории характеризуется аридностью климата. Большая часть его территории (66\%) может быть охарактеризована как засушливая, 24\% площадей относится к зоне достаточного увлажнения и только 10\% территории достаточно увлажнены. Летом в крае осадки чаще всего кратковременны, интенсивны и носят в основном ливневый характер. В этот сезон года нарастает повторяемость засушливых дней. Периодически, каждые 34 года отмечаются засухи. В предгорьях с мая по сентябрь их насчитывается до 10 дней, а к востоку их число постепенно увеличивается до 70. Количество дней с атмосферными засухами в этом направлении увеличивается с 50 до 95, наиболее часто они наступают в июле-августе. В целом, гидротермические условия края очень разнообразны и закономерно изменяются с запада на восток [1]. 
Из-за специфических погодных условий летних месяцев (июль, август) в крае складываются особые гидротермические условия, при которых температурные показатели достигают экстремально высоких цифр, а влажность почв, воздуха и количество осадков оказываются минимальными. При небольших значениях воздействия неблагоприятных факторов вегетация газонов и дерновых покрытий специального назначения, заметно угнетается. Недостаточно регулярно орошаемые газонные травы, сохраняющие ассимилирующие листья, в этот период замедляют рост «летняя депрессия роста». Наблюдается также снижение отавности газонного травостоя после его стрижки. Это происходит потому, что 97-99\% потребляемой растениями воды уходит на транспирацию, интенсивность которой пропорциональна ростовым процессам. В результате чего основной формой адаптации газонных злаков в этот период становится не снижение транспирации, а прекращение роста [6].

Известно, что засуха начинается как атмосферная, потом к ней присоединяется и почвенная. При затяжных, продолжительных засухах без полива адаптивная реакция газонных трав сводится к приостановлению их жизнедеятельности и переходу в состояние так называемой «скрытой жизни» (диапаузы), во время которой имеет место временный физиологический полупокой в индивидуальном развитии. При полном выгорании практически у всех основных видов газонных трав, традиционно используемых в газоноведении, может произойти отмирание их надземной части - «летний период полупокоя». Это выработанное в процессе эволюции приспособление к переживанию неблагоприятных периодов жизни сохранили не только наши местные ксерофитные, ксеромезофитные и мезофитные злаки, но и интродуцированные сортовые газонные. Выгоревшие газоны теряют декоративность, средообразующую роль, способность к регенерации.

После выпадения дождей или при возобновлении регулярного полива, даже полностью выгоревшие газонные травы снова начинают отрастать и зеленеть. При систематическом орошении газонов, с поддержанием уровня увлажнения почвы выше влажности замедления роста и при высоком уровне азотного питания, атмосферная засуха на рост трав практически не влияет [8].

Подавляющее большинство изучаемых нами в интродукционном эксперименте газонных злаков, которые также чаще всего используются в городах и населенных пунктах Ставропольского края для создания декоративных, спортивных газонов и дерновых покрытий специального назначения, являются северными, холодносезонными или бореальными видами. Эти травы, благодаря значительной биоэкологической пластичности, широте географического и экологического ареалов, могут произрастать в различных климатических условиях. Они пригодны для создания газонов широкого экологического и целевого диапазона. В эту группу входит подавляющее большинство газонных злаков - Festuca rubra L. (овсяница красная), F. pratensis Huds. (овсяница луговая), F. ovina L. (о. овечья), F. regeliana Pavl. (о. восточная), F. rupicola Heuff. (о. бороздчатая), Agrostis stolonifera L. (полевица побегообразующия), A. tenuis Sibth. (п. тонкая), Poa pratensis L. (мятлик луговой), P. angustifolia L. (м. узколистный), P. compressa L. (м. сплюснутый), Lolium perenne L. (райграс пастбищный), Bromopsis inermis (Leyss.) Holub. (кострец безостый), Phleum phleoides (L.) Karst. Dactylis glomerata L. (ежа сборная), Elytrigia intermedia (Host) Nevski (пырей средний), виды житняка (Agropyron Geartn. и др.). Оптимальная температура их роста $-23-24^{\circ} \mathrm{C}$, период вегетации в газонной культуре в зависимости от региона выращивания длится от нескольких десятков дней до круглогодичного срока. Продолжительность вегетации этой группы газонных трав в нашем крае в среднем составляет 240-260 дней (до 280 дней в восточных и северо-восточных районах).

Злаки южного субтропического и тропического происхождения теплолюбивы, могут выносить высокие температуры до $35^{\circ} \mathrm{C}$, более засухоустойчивы и жаростойки. В условиях нашего интродукционного эксперимента они отличаются более коротким периодом вегетации - 140-170 дней (середина мая - сентябрь-октябрь). Из этой группы злаков нами изучались Сynodon dactylon (L.) Pers. (свинорой пальчатый), Buchloe dactyloides (Nutt.) Engelm. (бухлоэ), Zosia japonica Steud. (цойсия японская).

Культивируемые в коллекции газонные и дернообразующие злаки отличаются значительным экологическим многообразием. К экологической группе мезофитов относится 38\% образцов 
коллекции, ксерофитов - 19\%, ксеромезофитов и мезоксерофитов $-40 \%$, гигромезофитов, мезогигрофитов и галофитов $-3 \%$.

Основные газонные травы коллекции относятся к первой группе качества, образуют высокодекоративные травостои и наиболее широко используются в крае для создания партерных газонов (мятлик луговой, овсяница красная, райграс пастбищный, полевица тонкая и п. побегообразующая). Они являются преимущественно мезофитами и обладают большой приспособленностью к окружающим условиям, выносят кратковременные водные дефициты и перегревы, имеют сбалансированный водный режим.

Ко второй группе качества газонных трав относятся злаки более широкого экологического разнообразия. Помимо мезофитов, это ксеромезофиты, мезоксерофиты, ксерофиты - виды житняков, мятлик сплюснутый, овсяница овечья, о. бороздчатая, о. луговая и др. (газоны обыкновенного, садово-паркового и лугового типа, дерновые покрытия специального назначения). Значительное экологическое разнообразие сохраняют газонные травы третьей группы качества - овсяница восточная, ежа сборная, тимофеевка луговая, т. степная, пырей бескорневищный, кострец безостый (задернение откосов дорог и гидросооружений, рекультивация выработок и карьеров).

П.А. Генкель рассматривает засуху как биолого-метеорологическое явление и характеризует ее наличием различной длительности бездождевых периодов с повышенной температурой воздуха, усилением испарения и транспирации из-за дефицита насыщения влажности воздуха, с перегревом и обезвоживанием растений, которые приводят к их повреждению и снижению продуктивности [4].

Для оценки засухоустойчивости газонных трав в условиях различного гидротермического режима Н.К. Коваленко [3] предложила 5-балльную шкалу:

- 5 баллов - высокая засухоустойчивость (эуксерофиты), хорошо переносят почвенную и воздушную засуху, могут обходиться без полива, но при поливе лучше растут;

- 4 балла - значительная засухоустойчивость (стипоксерофиты, ксерофиты), хуже переносят воздушную засуху и относительно устойчивы к почвенной, необходим умеренный полив;

- 3 балла - средняя засухоустойчивость (мезоксерофиты, ксеромезофиты), требовательны к почвенной засухе, нуждаются в систематическом поливе в течение всего летнего периода;

- 2 балла - малозасухоустойчивые растения (мезофиты, гигромезофиты), плохо переносят воздушную и почвенную засуху, нуждаются в систематическом поливе;

- 1 балл - незасухоустойчивые растения (мезогигрофиты, гигромезофиты), не мирятся ни с воздушной, ни с почвенной засухой, главным образом орошаемые культуры.

Исходя из представлений П.А. Генкеля о засухе как метеорологическом явлении, об интенсивности и продолжительности которого можно судить по степени воздействия на растительные объекты, мы предлагаем четырехбалльную визуальную шкалу выгорания неорошаемых газонных и дернообразующих травостоев:

I балл - слабая засуха, главным образом атмосферная. Газонный травостой теряет яркозеленую окраску и становится серовато-зеленым, преимущественно на открытых местах. Ассимилирующие листья не повреждаются.

II балла - засуха средней интенсивности, когда к атмосферной засухе добавляется почвенная. В аспекте травостоя газона до 50\% подсохших или фрагментарно пожелтевших стеблей и листьев.

III балла - сильная почвенная и атмосферная засуха средней продолжительности с высокими температурами воздуха и почвы, высоким дефицитом почвенной и атмосферной влажности. Выгорает более 50\% листьев травостоя газона.

IV балла - чрезвычайная засуха. Продолжительный бездождевой период с высокими температурами воздуха и почвы, с сильной почвенной и атмосферной засухой. Полное выгорание газонного травостоя. У газонов полностью высыхают листья и стебли, сплошной желтый аспект

Результаты исследования воздействия засушливых периодов на неорошаемые газонные травостои г. Ставрополя и культивируемые в коллекции газонные и дернообразующие злаки в течение 2000-2009 гг. представлены в таблице 1. 
Влияние погодных условий вегетационного периода на величину и степень выгорания неорошаемых газонных покрытий (г. Ставрополь)

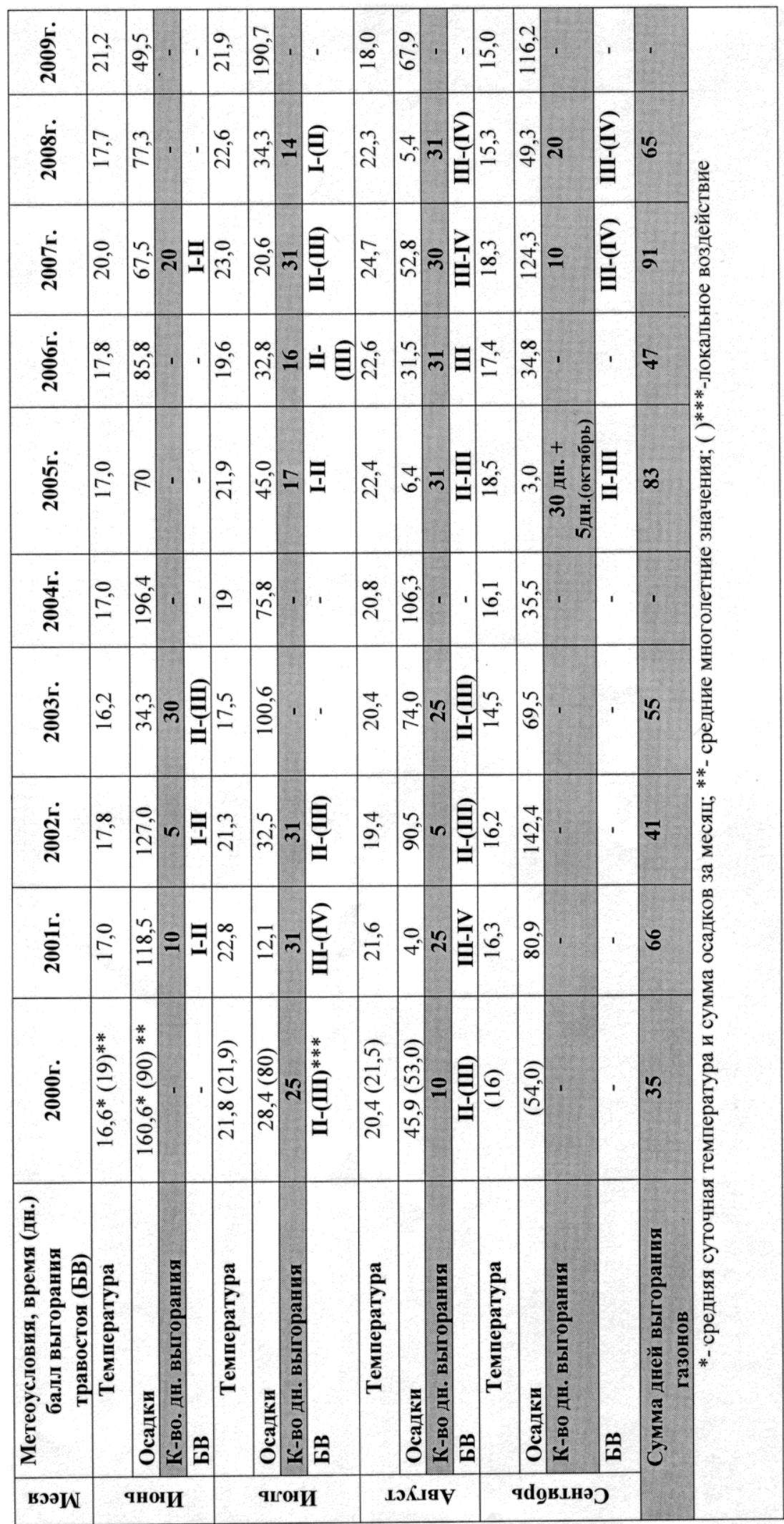


Десятилетний срок изучения воздействия засушливых явлений, приводящих к выгоранию неорошаемых или недостаточно орошаемых газонов в контролируемых стационарных условиях, позволили проанализировать возможные варианты складывающихся гидротермических ситуаций и оценить повторяемость, продолжительность и интенсивность периодов выгорания неорошаемых газонных травостоев.

В отдельные годы метеорологические условия колебались от полного отсутствия засухи и возможности содержания газонных травостоев в декоративном вегетирующем состоянии практически без полива (2004 и 2009 гг.), до чрезвычайных засух с выгоранием травостоя до III-IV баллов (2001, 2007, 2008 гг.), когда для поддержания газонов в вегетирующем состоянии необходим был регулярный полив. Различной была и длительность периодов выгорания от 35 дней (2000 г.) до 91 дня (2007 г.) и их интенсивность - от III баллов (2000, 2002, 2003, 2005, 2006 гг.) до III-IV баллов $(2001,2007,2008$ гг.). Различается и время наступления периодов выгорания: июнь-август (2001-2003 гг.), июль-август (2000, 2006 гг.), июль-октябрь (2005 г.), июнь-сентябрь (2007 г.), июль-сентябрь (2008 г.).

Практически во все сроки наблюдений, периоды выгорания были непрерывными, и только в 2003 г. было отмечено прерывистое течение засушливого периода. В июне и августе отмечено выгорание до II (III) баллов, в июле выпало много осадков, и выгоревший травостой возобновил вегетацию.

Относительная влажность воздуха в оптимальные для вегетации газонных трав периоды составляла $65-90 \%$, а в экстремально засушливые - 40-56\%. Влажность почвы в оптимально влагообеспеченные периоды была на глубине 0-10 см - 22,5\%, 10-20 см - 23,6\%, 20-30 см - 25,4\%, $30-40$ см - 26,2\%, в засушливые - соответственно 7,7\%, 8,1\%, 8,9\%, 10,1\%. Влажность завядания в этих же горизонтах почвы составляла соответственно 13,4\%, 13,6\%, 14,2\%, 15,7\% [10].

В первую очередь в условиях интродукционного эксперимента без орошения теряют декоративность и выгорают злаки бореального происхождения как инорайонные, так и местные дикорастущие мезофиты, ксеромезофиты и ксерофиты. Овсяница восточная, хотя и относится к экологической группе мезогигрофитов, обладает большей засухоустойчивостью. Она более устойчива, чем другие газонные злаки к выгоранию и раньше других отрастает в период возобновления вегетации. Большей жаро- и засухоустойчивостью отличаются также злаки, относящиеся к галофитам (пырей удлиненный, виды бескильниц и др.). Злаки южного происхождения также отличаются большой жаро- и засухоустойчивостью. Поэтому газоны из свинороя пальчатого, чаще всего взятого из местных дикорастущих популяций, используют в восточных районах края как в чистой культуре (городские газоны г. Нефтекумска), так и в смеси с другими злаками (спортивные газоны стадионов городов Буденновск и Нефтекумск; II очень засушливый агроклиматический район, ГТК $=0,5-0,7, \sum t^{\circ}>10^{\circ} \mathrm{C}-3400-3600^{\circ}$, годовая сумма осадков 300-375 мм). Наши исследования показали, что выращивание практически всех видов газонных злаков и поддержание их в декоративном, вегетирующем состоянии, при условии систематического орошения возможно даже в засушливых агроклиматических районах края.

Как было сказано выше, морфологическим признаком перехода многолетних трав в состояние летнего полупокоя служит быстрое подсыхание надземных побегов и листьев. У ксерофитов верхние листья более засухоустойчивы, чем нижние. При быстро нарастающей атмосферной засухе верхние листья оттягивают воду у нижних и ускоряют их усыхание. У мезофильных трав подсыхание побегов начинается с верхних листьев и точек роста, в то время как нижние листья еще некоторое время продолжают вегетировать.

Кратковременный летний полупокой связан с переходом меристемы точек роста в состояние торможения. Как правило, он наступает по мере ухудшения экологических условий, а выход из состояния покоя - по мере их улучшения.

Полупокой связан не только с резким уменьшением интенсивности физиологобиохимических процессов, но и с изменением направления этих процессов. У трав изменяется характер связи между подземными и надземными органами. В период интенсивного роста корневая система усиливает поставку воды и питательных веществ надземным побегам, а те в ответ увеличивают приток к корням возрастающего количества пластических веществ и рост корневой 
системы. Напротив, в период перехода растений в состояние полупокоя между его подземными и надземными органами устанавливается отрицательная связь. Корневая система растений сокращает подачу воды побегам. Происходит выгорание нижних листьев и ослабление обратного притока пластических веществ к корням, что ослабляет их жизнедеятельность.

При выходе из состояния полупокоя вновь происходит перестройка характера связей между надземными и подземными органами в обратном направлении: отрицательная обратная связь сменяется положительной [7].

Многолетние газонные злаковые травы благодаря наличию узлов кущения и корневищ могут переносить длительную засуху до двух месяцев и более. В качестве приспособления к летним гидротермическим стрессам В.В. Скрипчинский указывает на образование у многолетних трав укороченных вегетативных побегов и задержку их в укороченном состоянии вплоть до наступления благоприятного периода [17].

Проведение ежегодного мониторинга влияния засухи на газонные травы возможно лишь в стационарных условиях при систематических наблюдениях за их состоянием и параллельном контроле за метеорологическими параметрами вегетационного периода. Выявление в ходе исследований разногодичных вариантов длительности и интенсивности засушливых периодов и изучение реакций на них различных видов газонных трав могут послужить моделью для прогнозирования успешности их интродукции в различные агроклиматические районы края - от сухого и очень засушливого районов, где выращивание газонов возможно лишь в условиях практически постоянного орошения, до влажного и избыточно влажного, где полив может быть минимальным.

Как правило, выгорание газонного травостоя происходит постепенно по мере нарастания атмосферной и почвенной засухи.

В г. Светлограде (III засушливый агроклиматический район, ГТК $=0,7-0,9, \sum t^{\circ}>10^{\circ} \mathrm{C}-$ 3200-3500, годовая сумма осадков 350-450 мм) мы столкнулись с еще одним вариантом воздействия засушливых явлений - подсыханием листьев в зеленом виде на газоне из овсяницы красной, т.е. с эффектом подсушивания, называемым «захват». Его проявление возможно тогда, когда к почвенной и атмосферной засухе добавляются и суховейные явления [4].

Выгоревшие газоны теряют средообразующую способность и декоративные качества. Их травостой обладает пониженной регенеративной способностью из-за приостановления ростовых процессов.

Определение экологических характеристик выгоревшего (IV балла выгорания) и регулярно поливаемого в засушливые периоды газонов проводилось на стационарном участке с ровным рельефом и высотой травостоя 5-7 см. Параллельные измерения температуры и влажности выполнялись на поверхности газонов обоих вариантов в сухую безоблачную или малооблачную погоду в 13 часов, в 2005 г. в период с 9.08 до 30.09 (n=14 дней), в 2006 г. - 7.08-31.08 (n=11 дней), в 2007 г. - 6.08-5.09 (n=14 дней) (табл. 2). Как показали полученные данные, выгоревшие газоны теряют средообразующую способность, температура на их поверхности на 6-9 ${ }^{\circ} \mathrm{C}$ выше, чем на орошаемом газоне, а влажность ниже на 20-29\%. Гидротермические показатели на поверхности выгоревшего газона и обнаженной почвы довольно близки.

Параллельно учитывались температурные показатели в почве на глубине 5-10-15 см (рис. 1). Известно, что в почву под растительным покровом попадает меньше тепла, чем в обнаженную. У вегетирующих и выгоревших трав различная лучепоглотительная и лучеотражательная способность. Так, альбедо - отношение отраженной солнечной радиации к суммарной поступающей к поверхности почвы, у зеленой травы равно 26\%, а у высохшей - 19\%. Энергия солнца поглощается поверхностью почвы, превращается в тепловую энергию и передвигается от слоя к слою. Повышенная после поливов влажность почвы способствует тому, что часть поглощенной энергии расходуется на ее испарение. Поскольку температура поверхности при этом не повышается, то образуется лишь небольшой градиент, вызывающий тепловой поток в почву [11]. Этим и объясняется более высокая температура во всех точках измерения у выгоревшего газона в сравнении с регулярно поливаемым. 
Изменение микроклиматических показателей на поверхности регулярно орошаемого и выгоревшего газона (в 13 часов)

\begin{tabular}{|c|c|c|c|c|c|c|c|c|c|c|}
\hline 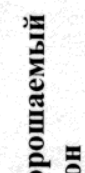 & 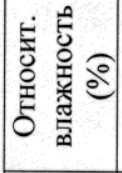 & $\frac{\tilde{H}}{n}$ & $\begin{array}{l}0 \\
0 \\
0 \\
0\end{array}$ & $\simeq$ & $\begin{array}{l}\infty \\
\text { ती } \\
\text {. } \\
0_{0}^{0}\end{array}$ & $\frac{\bar{i}}{\bar{n}}$ & $\infty$ & 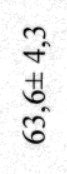 & $\begin{array}{l}\vec{T} \\
\hat{D} \\
i n\end{array}$ & ๙ิ? \\
\hline 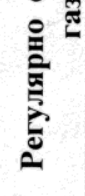 & 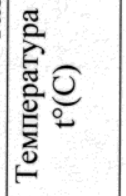 & $\begin{array}{l}\text { N } \\
\text { Hn } \\
n \\
\text { ô } \\
\text { ñ }\end{array}$ & 沅 & $\stackrel{\infty}{-}$ & $\begin{array}{l}n \\
0 \\
0 \\
0 \\
\tilde{n}\end{array}$ & $\frac{q}{d}$ & r & $\begin{array}{l}\vec{n} \\
\ddot{n} \\
\text { ले }\end{array}$ & 柿 & ๙n \\
\hline \multirow{2}{*}{ 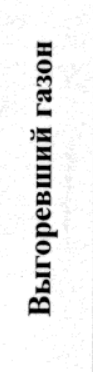 } & 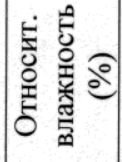 & 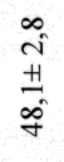 & $\begin{array}{l}\hat{\tilde{े}} \\
\text { ஸे }\end{array}$ & $\vec{\sim}$ & $\begin{array}{l}\overrightarrow{\text { N }} \\
\text { on } \\
\text { on }\end{array}$ & $\begin{array}{l}0 \\
\tilde{n} \\
\tilde{n}\end{array}$ & $=$ & $\frac{n}{\frac{n}{H}} \frac{0}{f}$ & $\begin{array}{l}\tilde{n} \\
\tilde{N} \\
\tilde{n}\end{array}$ & $\stackrel{n}{i}$ \\
\hline & 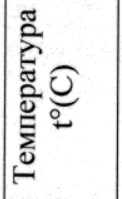 & $\begin{array}{l}\hat{0} \\
\stackrel{1}{n} \\
\text { m }\end{array}$ & $\frac{d}{d}$ & $=$ & 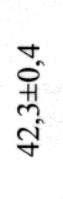 & $\begin{array}{l}\tilde{N} \\
\infty \\
\infty \\
\tilde{n}\end{array}$ & $m$ & $\begin{array}{l}\hat{F} \\
\dot{H} \\
\dot{q}\end{array}$ & 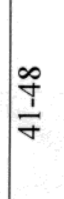 & $\stackrel{\forall}{ \pm}$ \\
\hline \multirow{2}{*}{ 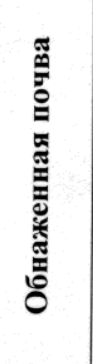 } & 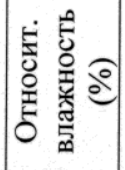 & $\frac{m}{H}$ & $\begin{array}{l}\tilde{1} \\
\text { bे } \\
\text { No }\end{array}$ & \pm & $\begin{array}{l}\overrightarrow{+} \\
\vec{H} \\
\dot{m}\end{array}$ & 文 & $\Xi$ & $\begin{array}{l}- \\
\vec{H} \\
\underline{H} \\
\infty \\
m\end{array}$ & 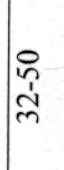 & فे \\
\hline & 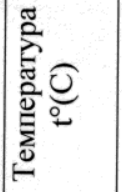 & $\begin{array}{l}\text { Oे } \\
\text { 표 } \\
\text { को }\end{array}$ & †े & 은 & $\begin{array}{l}= \\
\vec{H} \\
n \\
\dot{y}\end{array}$ & n̂̀ & $\infty$ & $\begin{array}{l}1 \\
\text { H } \\
+ \\
\text { fo }\end{array}$ & \begin{tabular}{l}
\multirow{2}{*}{} \\
ลิ่
\end{tabular} & $\hat{\sigma}^{2}$ \\
\hline \multirow{2}{*}{ 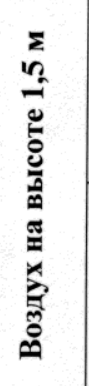 } & 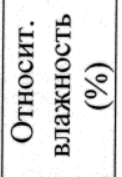 & $\begin{array}{l}n \\
\text { i } \\
y \\
y \\
o \\
o\end{array}$ & 嶽 & 2 & 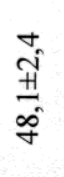 & 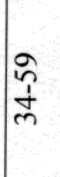 & సి & $\begin{array}{l}\text { aे } \\
\text { H } \\
\text { in } \\
\text { f }\end{array}$ & $\begin{array}{l}\tilde{n} \\
\tilde{n} \\
\tilde{n}\end{array}$ & $\hat{a}$ \\
\hline & 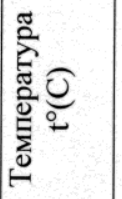 & $\begin{array}{l}m \\
\vec{H} \\
n \\
\dot{N}\end{array}$ & $\stackrel{\sim}{\underline{n}}$ & సి & $\begin{array}{l}\hat{\circ} \\
\text { मे } \\
\text { ते }\end{array}$ & $\hat{\hat{n}}$ & $a$ & $\begin{array}{l}n \\
0 \\
\text { मn } \\
\text { ñ }\end{array}$ & సิ & ñ \\
\hline \multicolumn{2}{|c|}{ 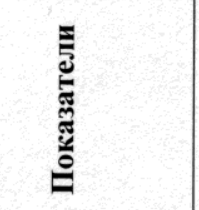 } & $\sum_{\Sigma}^{E}$ & 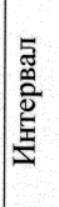 & 己 & $\sum_{\Sigma}^{E}$ & 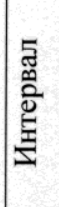 & 己 & ${ }_{\Sigma}^{E}$ & 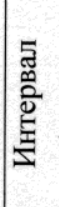 & $\vec{u}$ \\
\hline \multicolumn{2}{|c|}{$\stackrel{5}{\mathscr{5}}$} & \multicolumn{3}{|c|}{ 气ू̆ } & \multicolumn{3}{|c|}{ 芯 } & \multicolumn{3}{|c|}{ ث્ّ } \\
\hline
\end{tabular}



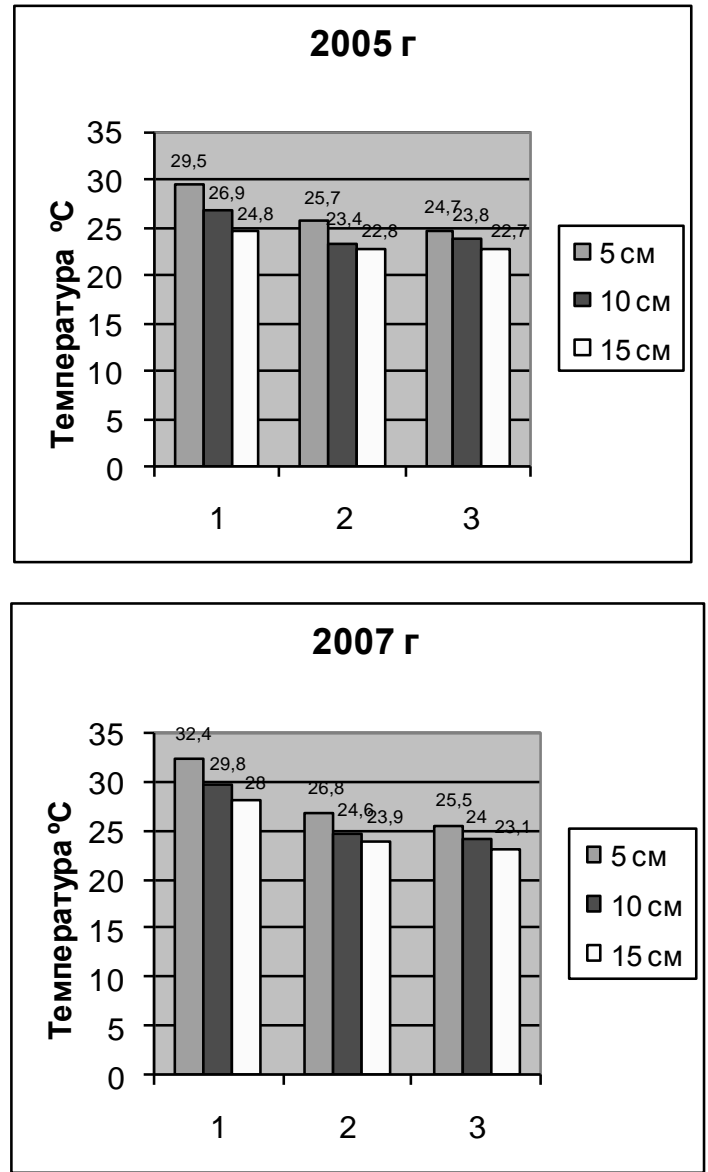

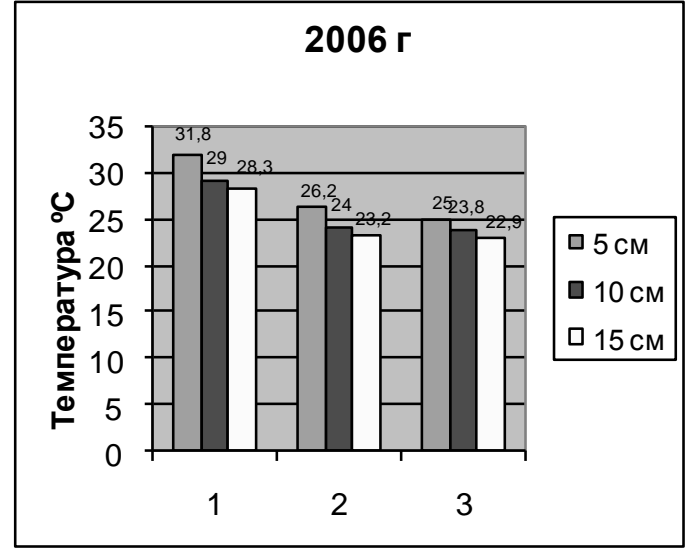

Рис. 1. Температурные показатели $\left({ }^{\circ} \mathrm{C}\right)$ почвы на глубине 5 см, 10 см, 15 см обнаженной почвы (1), выгоревшего газона (2), регулярно орошаемого газона (3)

Таким образом, наши исследования показали, что:

1. Культивирование газонов и дерновых покрытий специального назначения в большинстве агроклиматических районов Ставропольского края (главным образом степная зона) проходит в неблагоприятных фоновых засушливых климатических условиях, далеких от климатического оптимума наиболее широко используемых газонных и дернообразующих трав. Основными лимитирующими экологическими факторами засушливых периодов, препятствующими их активной вегетации в неорошаемых условиях, является недостаток продуктивной влаги в почве в сочетании с минимальной относительной влажностью воздуха и аномально высокими температурами воздуха и почвы.

2. Длительная экстремальная гидротермическая ситуация засушливого периода (главным образом июль, август) в отсутствии орошения приводит к депрессии роста газонных трав и их выгоранию - «летнему периоду полупокоя», временному физиологическому покою в индивидуальном развитии. Для характеристики интенсивности и продолжительности воздействия засушливых периодов на неорошаемые газонные и дерновые покрытия предложена 4-х балльная шкала визуальной оценки их выгорания. В зависимости от межгодовых климатических флюктуаций периодов засухи, в условиях V-го умеренно влажного агроклиматического района происходит выгорание различной интенсивности на период от 20 до 90 дней. Выгоревшие газоны теряют декоративность и средообразующую способность. Температура на поверхности выгоревшего до 4 баллов газона на 6-9 C выше, чем на регулярно орошаемом, а влажность - на 20-29\% ниже.

3. На основе изучения потенциальных приспособительных реакций интродуцированных газонных трав на экстремальные экологические ситуации засушливых периодов можно дать интродукционный прогноз перспективности их выращивания в засушливых агроклиматических районах края и в соответствии с их адаптивным потенциалом и присущими им нормами реакции, разработать перспективный ассортимент газонных и дернообразующих трав. Наши исследования показали, что выращивание практически всех видов традиционно используемых газонных злаков и поддержание их в вегетирующем декоративном состоянии при условии регулярного орошения, 
возможно даже в засушливых агроклиматических районах края. Для партерных газонов здесь могут быть использованы овсяница красная, мятлик луговой, м. узколистный, райграс пастбищный. Для обыкновенных, луговых газонов и дерновых покрытий специального назначения могут использоваться более жаростойкие и засухоустойчивые злаки - овсяница восточная, свинорой пальчатый, виды житняков, галофитные злаки (пырей удлиненный, виды бескильниц и др.).

\title{
Библиографический список
}

1. Агроклиматические ресурсы Ставропольского края. - Л.: Гидрометиздат, 1971.- 238 с. 2. Газоноведение и озеленение населенных территорий. / В.А. Тюдьдюков, И.В. Кобозев, Н.В. Парахин; Под ред. В.А. Тюльдюкова. - М.: Колосс, 2002. - 264 с. 3. Газоны. Научные основы интродукции и использования газонных и почвопокровных растений. - М.: Наука, 1977. - 244 с. 4. Генкель П.А. Физиология жаро- и засухоустойчивости растений. - М., Высшая школа, 1979. - 368 с. 5. Горышина Т.К. Экология растений: учеб. пособие. - М.: Высш. школа, 1979. - 368 с. 6. Коробкин В.И., Передельский Л.В. Экология. - Ростов н/Д: Феникс, 2006. - 608 с. 7. Куркин К.А. Летний и многолетний покой травянистых многолетников Барабинской степи. // Ботанический журнал. - 1971. - № 11. - С. 1565-1580. 8. Куркин К.А. Закон минимума и факторы, лимитирующие продуктивность луговых фитоценозов. // Экология. - 1996. - №5. - С. 341-344. 9. Лаптев А.А. Газоны. - Киев: Наукова думка, 1983. - 176 с. 10. Методика расчета запасов влаги в почвах Ставропольского края. / Составитель М.Т. Куприченков. - Ставрополь: ГУП «Ставропольская краевая типография», 2004. - 42 с. 11. Муха В.Д., Карамышев Н.И., Муха Д.В. Агропочвоведение. / Под ред. В.Д. Мухи. - М.: Колосс, 2003. 528 с. 12. Павлова М.Д. Практикум по сельскохозяйственной метеорологии. М.: Колос, 1968. - 200 с. 13. Плохинский Н.А. Биометрия. - М.: Колос, 1968. - 202 с. 14. Полевая геоботаника. Т.1. - М.-Л.: Изд-во АН СССР, 1959. - 444 с. 15. Природный комплекс большого города: Ландшафтно-экологический анализ. / Э.Г. Коломыц, Г.С. Розенберг, О.В. Глебова и др. - М.: «Наука/Интерпериодика», 2000. - 286 с. 16. Психрометрические таблицы. / Составители Беспалов Д.П., Матвеев Л.Т., Козлов В.Н. и др. - Л.: Гидрометиоиздат, 1981. - 270 с. 17. Скрипчинский В.В. Некоторые закономерности онтогенеза многолетних и однолетних кустовых злаков:- Автореф. дис. докт. биол. наук. Ставрополь Кавказский, 1958. - 36 с.

\section{УДК 582.06 (470.67)}

\section{ТАКСОНОМИЧЕСКАЯ СТРУКТУРА ФЛОРЫ ПРИМОРСКОЙ НИЗМЕННОСТИ РЕСПУБЛИКИ ДАГЕСТАН}

\author{
$\odot_{2010}$ Солтанмурадова 3.И., Теймуров А.А. \\ Дагестанский государственный университет
}

Анализируется таксономический состав флоры Приморской низменности. Рассчитаны коэффрициенты ее ранговой корреляции с другими фрорами. Сделаны выводы о влиянии сопредельных фрлор на таксономический состав фрлоры Приморской низменности.

The kofficients of its rang carrelation the other flora types are calculated. There are made the conclustions about the influence of the nearly flora types according to the taxonomic composition of the Dagestan coastal lowland.

Ключевые слова: Приморская низменность, естественная фрлора, таксономический анализ, коэффициент ранговой корреляции.

Keywords: Primorskaya coastal lowland, natural flora, taxonomic analysis, kofficient of range correlation.

Приморская низменность Дагестана представляет собой узкую (длина около 160 км, ширина - 10-40 км) абразионно-аккумулятивную равнину со слабым уклоном в сторону моря. Северная граница низменности проходит по широте Махачкалы, южная - дельта Самура, восточная берег Каспийского моря, западная - предгорья Восточного Дагестана. Низменность образована комплексом древнекаспийских террас в основном хвалынского возраста. Примыкающая к склонам предгорий более приподнятая часть сложена преимущественно нижне- и верхнехазарскими 